\title{
Ground Magnetic Study for Characterization of Mineral Potential in Alajawa Area in Shanono, Kano State, of Nigeria
}

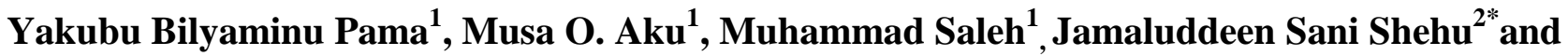 \\ Isah Aliyu Ngoba ${ }^{3}$ \\ ${ }^{1}$ Department of Physics, Faculty of Physical Sciences, Bayero University Kano, Nigeria \\ ${ }^{2}$ Department of Physics, Faculty of Science, Usmanu Danfodiyo University, Sokoto, Nigeria \\ ${ }^{3}$ Nigerian Metrological Agency (NIMET)
}

\begin{abstract}
Ground magnetic survey was carried out using Scintrex proton precession magnetometer to map out subsurface structures and mineralization potentials at Alajawa area in Shanono, Kano State. 2D forward modelling was in the delineation of geological structures that are potential mineralization zones. Surfer 15 software was used to produce residual contour map. A total of five (5) profiles of the magnetic residual anomalies were modelled using Mag2dc software. The mineral potential locations were identified. The major zones with potential of mineral resources were located at the depth of $14.81 \mathrm{~m}, 1.71 \mathrm{~m}, 10.83 \mathrm{~m}, 14.25 \mathrm{~m}$, and $15.38 \mathrm{~m}$ along profile $A A^{\prime} ; 3.42 \mathrm{~m}, 10.01 \mathrm{~m}, 15.95 \mathrm{~m}, 7.41 \mathrm{~m}$, and $2.28 \mathrm{~m}$ along profile $B B^{\prime} ; 20.51 \mathrm{~m}, 11.97 \mathrm{~m}, 2.28 \mathrm{~m}$, and $27.35 \mathrm{~m}$ along profile CC'; $3.99 \mathrm{~m}, 2.85 \mathrm{~m}, 5.13 \mathrm{~m}$, and $6.27 \mathrm{~m}$ along profile DD'; $34.76 \mathrm{~m}, 25.64 \mathrm{~m}, 7.98 \mathrm{~m}$, and $8.55 \mathrm{~m}$ along profile EE'. The bodies display susceptibility as high as 5.3380 SI Unit and as low as -06.745 SI Unit. The results of the research analysis revealed that subsurface is composed of limestone, sandstone and shale, granite or rhyolite rocks, gneiss, schist, slate and quartzite.
\end{abstract}

Keywords: Alajawa, Geological structure, Ground magnetic, potential mineral zones.

\section{INTRODUCTION}

The Nigerian economy is one majorly dependent on its oil and gas sector. Consequently, a drop in the commodity prices in recent years has contributed to a drop in GDP contribution. The current administration under the leadership of President Muhammadu Buhari is determined to explore other sectors of the economy particularly Agriculture and Solid mineral sectors to boost revenue and reduce unemployment (Nigerian Mining and Metal Sector Investment Brochure, 2017)

Use of geophysical methods to determine the targets has helped over the years in saving time and cost as well as reducing risk. Nearly every major mine in the world, at one time, used geophysics to explore and identify the natural resource (Shehu et al., 2021).

The discovery and location of these mineral ores can be detected through several geophysical techniques (Foley, 1994; Gibson et al., 1996; Marchetti, et al., 1980). Efforts have been made by geophysical and mining engineers to find the meaning of the structure of the outermost formation of the earth crust. These have led to diverse comprehensive studies, which now stand as building block to their efforts.

Magnetic survey is probably the oldest branch of geophysics. In exploration, acquisition of magnetic measurements is usually airborne, ground, on the ocean, in space, and down boreholes. It may cover a large range of scales and for a wide variety of purposes. Ground magnetics can provide a better perspective of the bedrock geology and structures. Magnetic survey is a wellknown technique to delineate subsurface structures and has been extensively used in many parts of the world. Magnetic susceptibility is the significant variable in magnetic survey. Sheriff (1928) noted that magnetic anomalies are caused by magnetic minerals (mainly magnetite and pyrrhotite) contained in rocks. Most rock forming minerals are magnetized by induction in the Earth's field, and cause spatial perturbations or "anomalies" in the Earth's main field (Telford et al., 1990). They further 
emphasized that man-made objects such as iron or steel are highly magnetized and locally will cause compromised magnetic anomalies up to several thousands of Nano Tesla (nT).

The magnetic method has been utilized in mapping basement, locating faults, defining lithological contacts, archeological investigations, mapping salt domes and to better define targets through inversions. Magnetic survey has evolved from mapping basement (igneous) structures into new applications-oil and gas, geothermal resources, natural hazards and risk assessment, engineering structures, environmental studies and precious and base metal exploration. Magnetic surveys have had successes as an airborne tool, on ground and on sea. It has also been utilized for planetary studies as well. The magnetic technique involves measuring the amplitude measure of the magnetic field at distinct points. These regularly distributed points are along planned survey lines throughout the area of interest.

In this research, ground magnetic was measured with a proton precision instrument with accuracy of $0.1 \mathrm{nT}$ at a regular interval of $1 \mathrm{~m}$ on $50 \mathrm{~m}$ traverse line interval to determine mineralization potential. The traverse lines are perpendicularly oriented north-east to the general strike direction (base line) of the survey area.

\section{MATERIALS AND METHOD}

\section{Material}

1. Proton-precession magnetometer

2. Surfer 15 software

3. Mag2DC software

\subsection{Method}

Ground magnetic measurements were undertaken along profiles at intervals of 50m using the Proton-Precession Magnetometer (PPM). To achieve measurements in the order of $1 \mathrm{nT}$ or less, several precautions were taken into account. The PPM operator had to be relatively free of any magnetic materials on his person, e.g. pocket knives, metal clipboards, mobile phones, etc. The sensor was kept clean to avoid possible contamination by magnetite-bearing dirt on the sensor surface. The sensor was mounted on a 2.4 $\mathrm{m}$ staff in order to remove it from locally disturbing effects of highly magnetic surface materials such as highly magnetic out cropping rocks.

The total magnetic field intensity component was recorded throughout the survey period and at each station. Repeated readings were made at the base station each day, at most, after one-hour interval with the same PPM.

The data collected composed of the total magnetic intensity, the coordinates of the observation and time of acquisition. Fifteen profiles were developed at regular interval of 50m traverse line.

\subsection{Data Correction}

Prior to mapping the ground magnetic data, principal corrections were done to eliminate the effects diurnal variations. The magnetic data were corrected by using Equations (1) and (2):

$$
D_{\text {rift }}=\frac{B \text { base }, f-B \text { base }, i}{t \text { base, } f-t \text { base }, i}
$$

where Drift is the drift of measurement in a loop; B base, $\mathrm{f}$ and B base, i are the final and initial total magnetic field at the base station; tbase, $f$ and tbase, $i$ are the final and initial time at the base station.

The drift corrected field at any station in the loop for a given day was calculated from: $\quad B_{\text {driftn }}=$ $B_{n}-\operatorname{Drift}\left(t_{n}-t_{\text {base }}\right)$

where $B_{\text {driftn }}$ is corrected magnetic field at the $\mathrm{n}^{\text {th }}$ station in the loop; $B_{n}$ is the total magnetic field at the $\mathrm{n}^{\text {th }}$ station; $t_{n}$ is the measuring time at the $\mathrm{n}^{\text {th }}$ station; $t_{\text {base }}$ is the measuring time at the first station of the loop.

\subsection{D Forward Modelling}

To determine the causative parameters, modeling of the anomalies was carried out using mag2dc software. This involves an attempt to match the observed anomaly with the calculated one by making iterative adjustments to the model.

Surfer software was used for the gridding and to plot contour map to establish anomaly signature of the area and five profiles were drawn across anomalous zones. 


\section{RESULTS}

Figure 1. shows the five profiles drawn on the residual map (the residual map here is generated with Surfer 15). These profiles, named AA', BB' CC', DD', and EE', are drawn across different anomalous points.

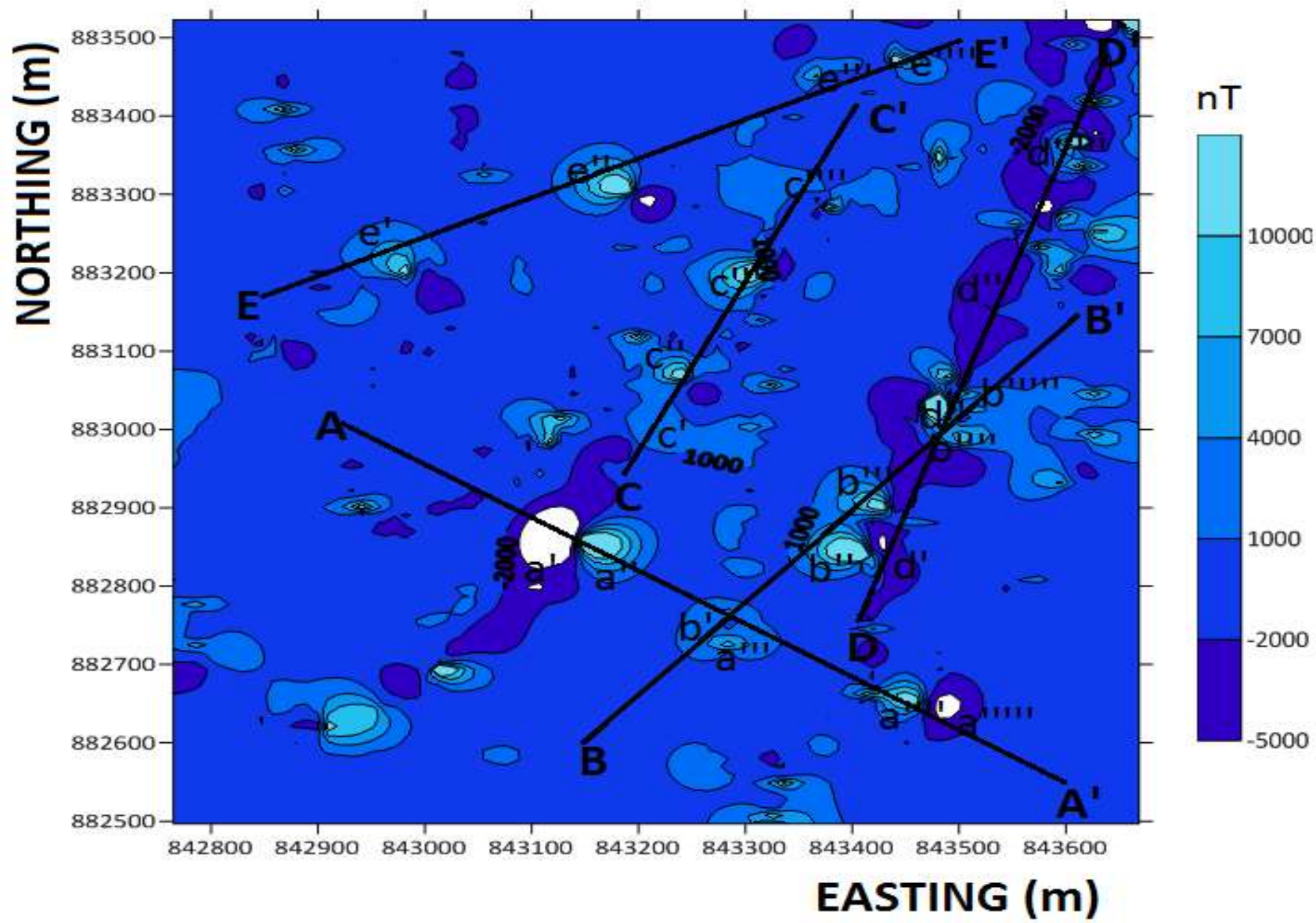

Figure 1. Profile Contour Map

Figures 2 to 6 show the modelled bodies of the subsurface geology structures causing anomalies on the selected profiles.

The causative parameters obtained for the bodies are depth extent, depth to body, max width and susceptibility values. The susceptibility values were compared with standard susceptibility value of rocks and minerals to obtain the rock interpretations. Details of the causative parameters and rock interpretations are presented in Table $1 \& 2$ respectively. 
International Journal of Advances in Scientific Research and Engineering (ijasre), Vol 7 (7), July-2021

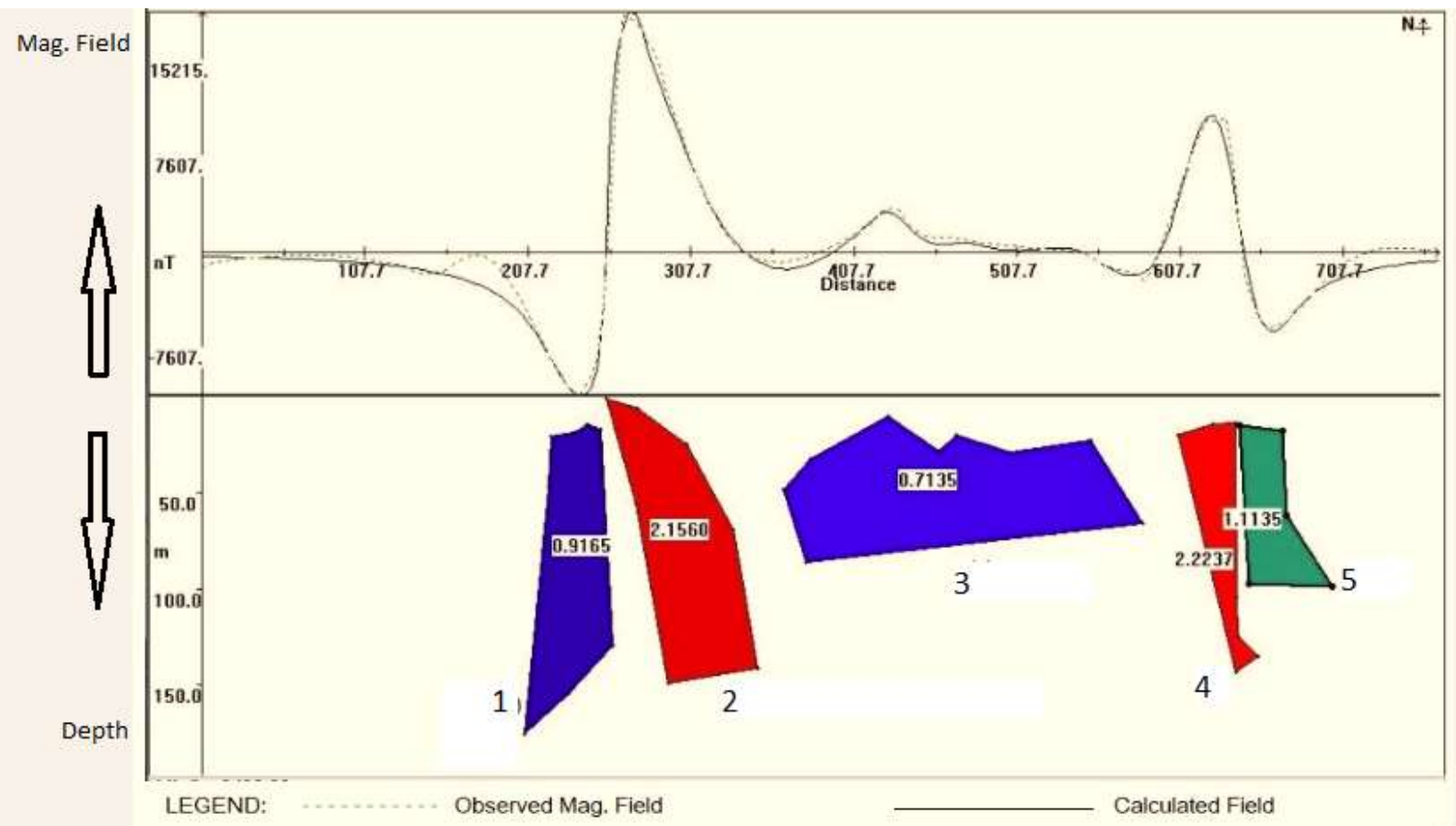

Figure 2 Magnetic models along profile AA'

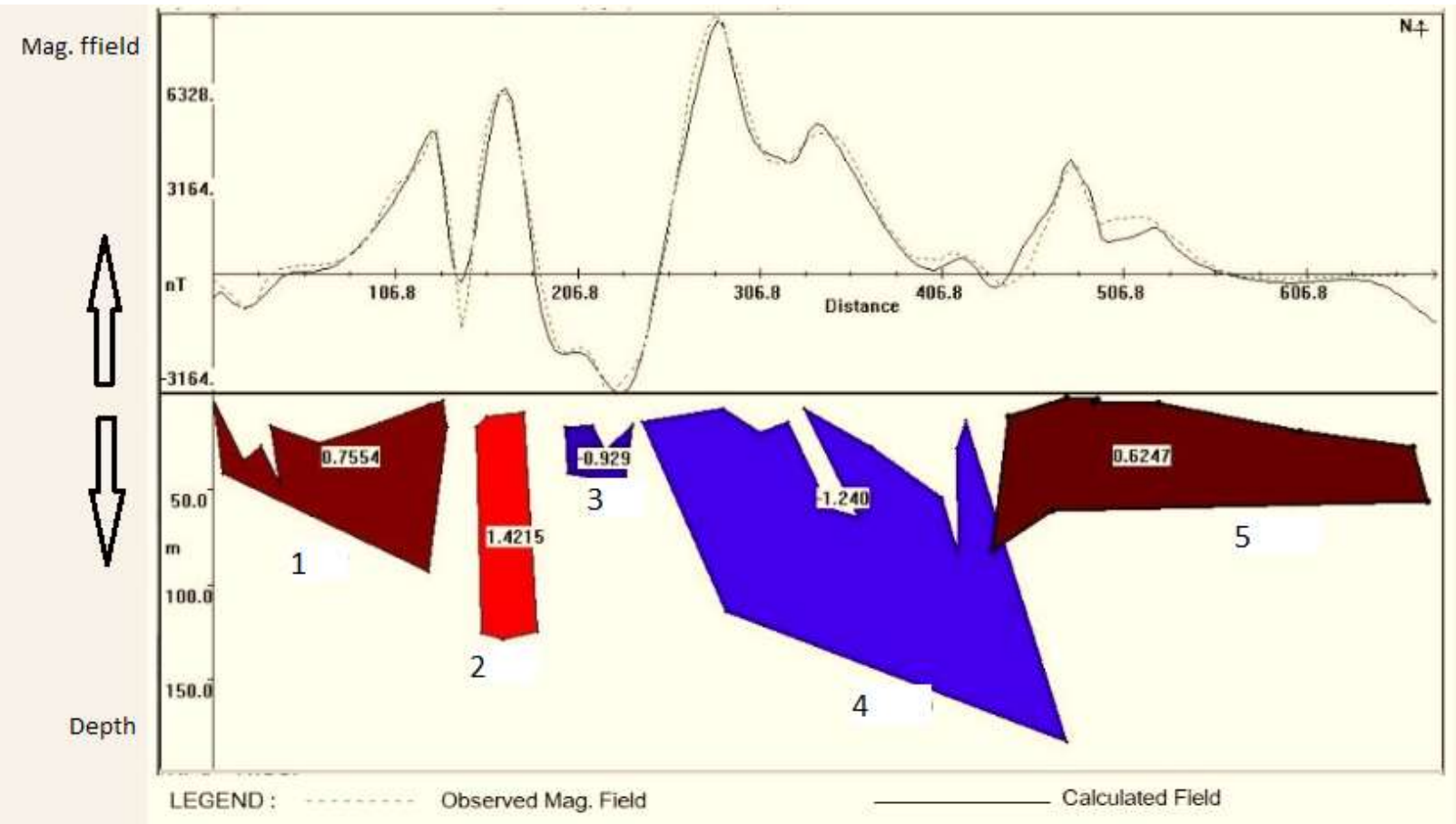

Figure 3 Magnetic models along profile BB' 
International Journal of Advances in Scientific Research and Engineering (ijasre), Vol 7 (7), July-2021

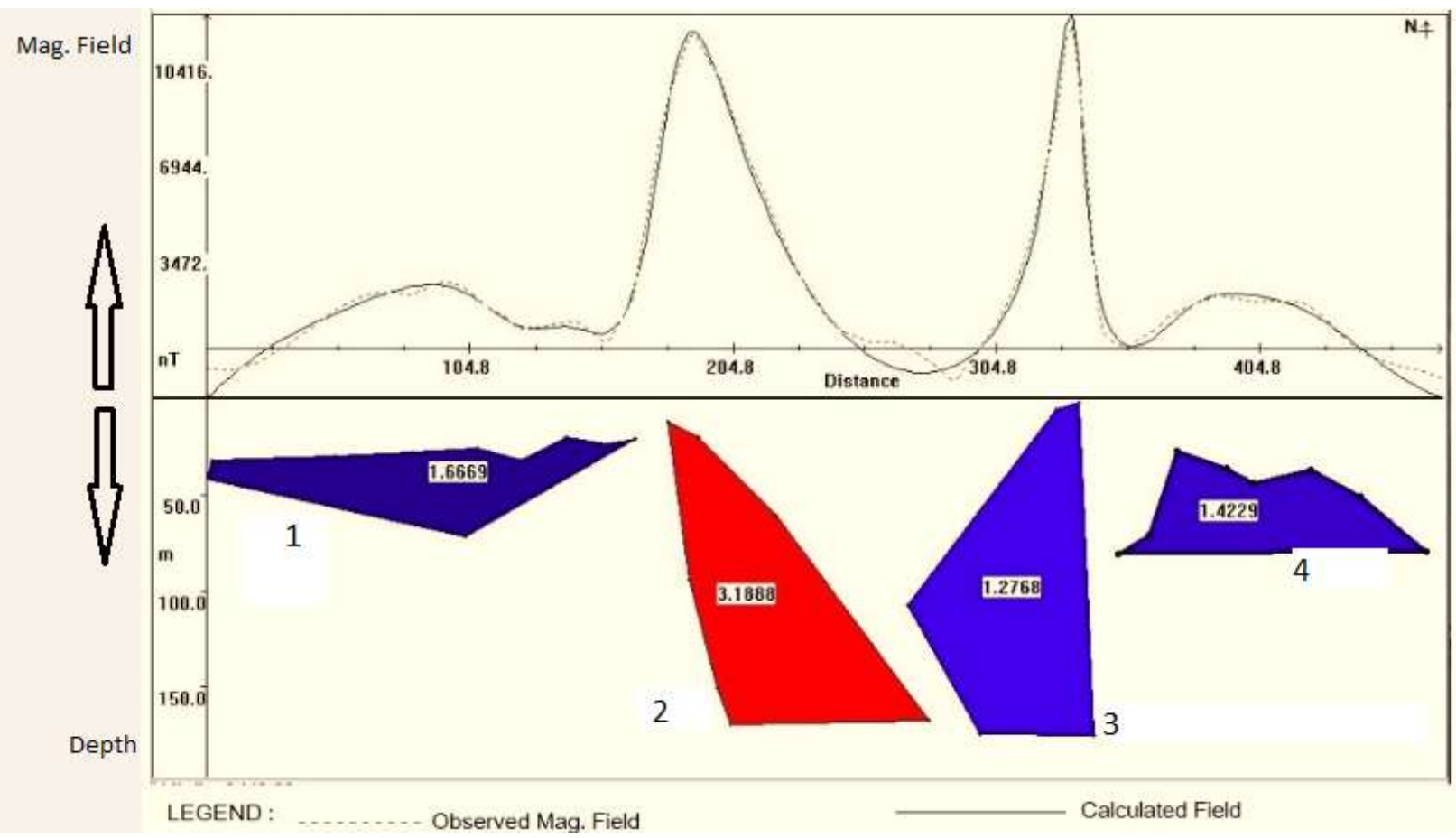

Figure 4. Magnetic models along profile CC'

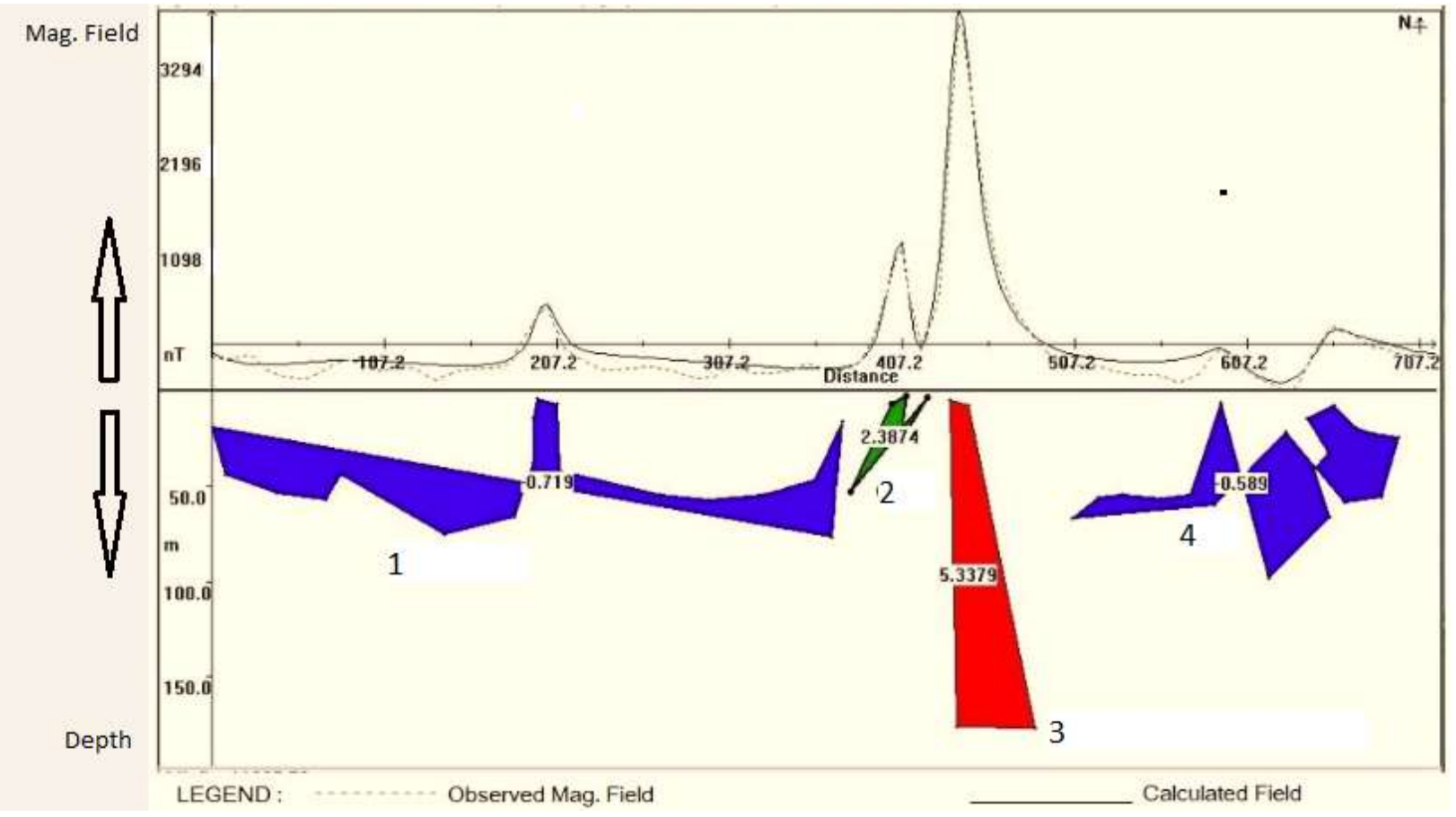

Figure 5. Magnetic models along profile DD' 


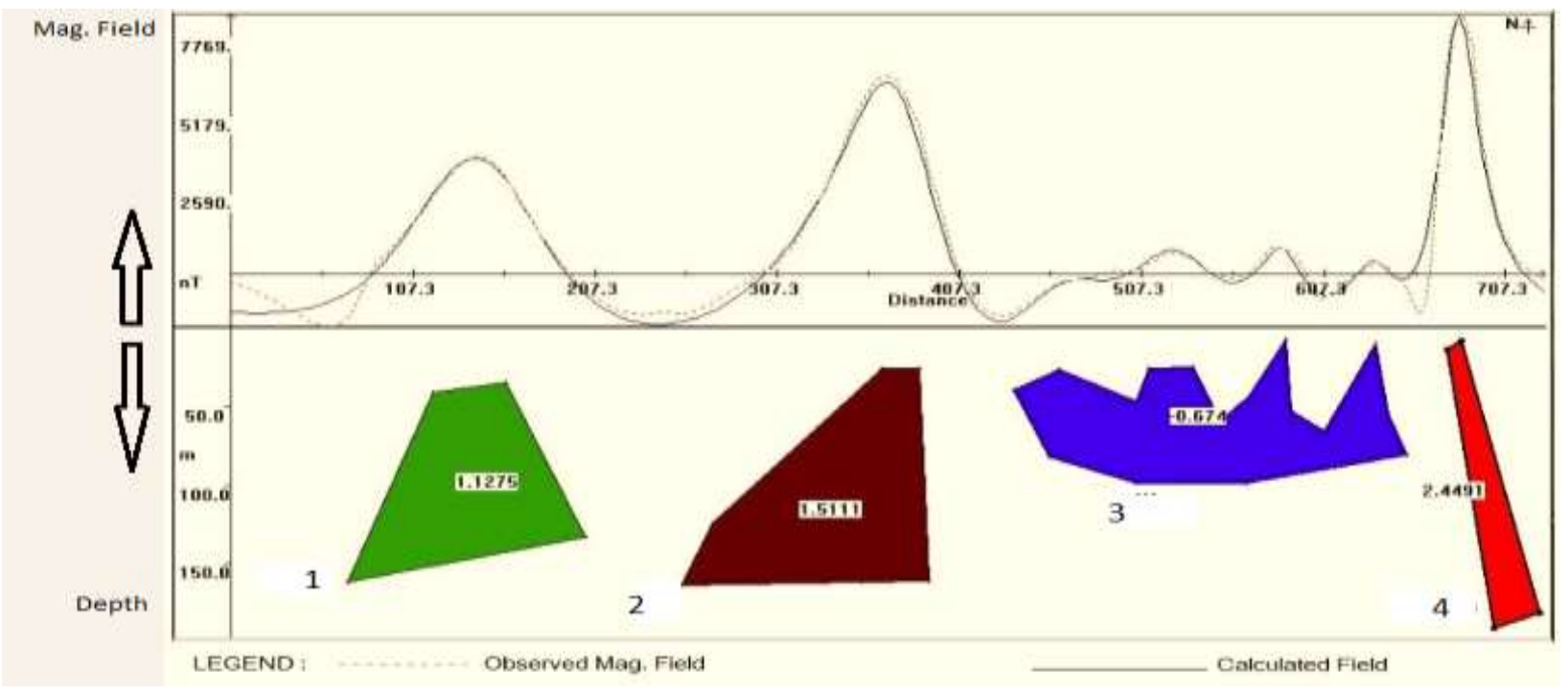

Figure 6. Magnetic models along profile EE'

Profile AA' trends NW-SW in the residual contour map. The model on the profile shows five causative bodies in Figure 2. The second and fourth bodies have susceptibilities values of $2.1560 \mathrm{SI}$ and $2.2237 \mathrm{SI}$ at the depths of $1.71 \mathrm{~m}$ and $14.25 \mathrm{~m}$ respectively. The fifth body has susceptibility value of 1.1135 SI at the of depth 15.38 . These susceptibility values suggest that the bodies are composed of limestone, sandstone, shale, schist and gneiss.

Profile BB' trends NE-SE in (Figure 3) shows five causative bodies. The first body of susceptibility value of 0.7554 SI is located at a depth of about $3.42 \mathrm{~m}$, the second body at a depth of $10.01 \mathrm{~m}$ has a susceptibility value $1.4215 \mathrm{SI}$ and the fifth body at a depth of $2.28 \mathrm{~m}$ has a susceptibility value $0.6247 \mathrm{SI}$ postulated to be limestone and sandstone, slate and granite. Adjacent to first, second and fifth bodies are bodies of negative susceptibility values of -0.9299 SI and -1.240 SI respectively. The two bodies with negative susceptibility are reversely magnetized.

The magnetic anomaly on profile CC' (Figure 4) is on the NE-SW part of the study area. The model on the profile shows four causative bodies. The first, second, third and fourth bodies are at depth of $20.51 \mathrm{~m}, 11.97 \mathrm{~m}, 2.28 \mathrm{~m}$, and $27.35 \mathrm{~m}$ while their susceptibility values are 1.6670 SI, 3.1888 SI, 1.2768 SI, and 1.4229 SI respectively. These indicate the presence of limestone, sandstone, shale, schist and gneiss.

Profile DD' is on the eastern region of the residual contour map. It trends from NE-SE in the study area. On this profile, five bodies of different magnetic susceptibility and depth are modeled. The bodies are postulated to be slate and granite.

Profile EE' trends NW-NE in the residual contour map. The profile has four causative bodies with different magnetic susceptibility and depth. The bodies postulated to schist, gneiss slate, granite and large quartz.

Other causative parameters obtained for the bodies are depth extent and max width. Summary of the causative parameters and rock interpretations are presented in Tables 1 and 2 respectively.

Table 1. Modelled Parameters of the Causative Bodies

\begin{tabular}{|c|c|c|c|c|c|c|c|}
\hline \multirow{2}{*}{$\begin{array}{l}\text { Profile } \\
\text { Name }\end{array}$} & \multirow{2}{*}{$\begin{array}{c}\text { Causative } \\
\text { Bodies }\end{array}$} & \multicolumn{2}{|c|}{ Location (m) } & \multirow{2}{*}{$\begin{array}{c}\text { Depth } \\
\text { Extent (m) }\end{array}$} & \multirow{2}{*}{$\begin{array}{l}\text { Depth to } \\
\text { Body (m) }\end{array}$} & \multirow{2}{*}{$\begin{array}{c}\text { Max width } \\
\text { (m) }\end{array}$} & \multirow{2}{*}{$\begin{array}{c}\text { Susceptibility } \\
\text { SI }\end{array}$} \\
\hline & & $\mathbf{X}$ & $\mathbf{Y}$ & & & & \\
\hline \multirow[t]{5}{*}{$\mathbf{A A}^{\prime}$} & a' & 843095.6 & 882876.6 & 161.25 & 14.81 & 53.87 & 0.9165 \\
\hline & a" & 843109.3 & 882848.4 & 148.15 & 1.71 & 93.05 & 2.1561 \\
\hline & a", & 843277.8 & 882732.0 & 75.78 & 10.83 & 220.99 & 0.7135 \\
\hline & a"," & 843444.4 & 882666.1 & 129.91 & 14.25 & 48.97 & 2.2238 \\
\hline & a",", & 843490.9 & 882619.6 & 83.76 & 15.38 & 56.93 & 1.1135 \\
\hline \multirow[t]{5}{*}{ BB' } & b' & 843258.4 & 882735.9 & 90.52 & 3.42 & 128.18 & 0.7555 \\
\hline & b" & 843366.9 & 882829.0 & 119.09 & 10.01 & 33.76 & 1.4216 \\
\hline & b"' & 843409.5 & 882937.6 & 31.91 & 15.95 & 37.37 & $\begin{array}{l}-0.9299 \\
\end{array}$ \\
\hline & b"', & 843452.1 & 882999.6 & 175.50 & 7.41 & 232.90 & -1.2400 \\
\hline & b",", & 843490.9 & 883061.7 & 80.34 & 2.28 & 239.93 & 0.6247 \\
\hline $\mathrm{CC}^{\prime}$ & c' & 843250.6 & 882984.1 & 51.49 & 20.51 & 172.93 & 1.6670 \\
\hline
\end{tabular}


International Journal of Advances in Scientific Research and Engineering (ijasre), Vol 7 (7), July-2021

\begin{tabular}{|c|c|c|c|c|c|c|c|}
\hline & c'" & 843239.0 & 883096.6 & 157.83 & 11.97 & 99.19 & 3.1888 \\
\hline & c"” & 843285.5 & 883181.9 & 173.22 & 2.28 & 70.41 & 1.2768 \\
\hline & c"', & 843332.0 & 883313.7 & 53.56 & 27.35 & 116.98 & 1.4229 \\
\hline \multirow[t]{4}{*}{ DD' } & d' & 843448.3 & 882809.6 & 72.82 & 3.99 & 370.45 & -0.7194 \\
\hline & d"' & 843456.0 & 883057.8 & 50.14 & 2.85 & 44.60 & 2.387 \\
\hline & d"', & 843521.9 & 883178.0 & 172.65 & 5.13 & 49.17 & 5.3380 \\
\hline & d"', & 843572.3 & 883325.4 & 92.31 & 6.27 & 188.69 & -0.5897 \\
\hline \multirow[t]{4}{*}{ EE' } & e' & 842956.1 & 883212.9 & 127.64 & 34.76 & 13.93 & 1.1275 \\
\hline & e" & 843165.4 & 883329.2 & 139.03 & 25.64 & 135.85 & 1.5111 \\
\hline & e"," & 843359.1 & 883468.9 & 91.41 & 7.98 & 216.48 & -0.6745 \\
\hline & e"," & 8434.67 .6 & 883461.1 & 182.91 & 8.55 & 50.73 & 2.4492 \\
\hline
\end{tabular}

From Table 1, the depth to body ranges from 1.71 to $34.76 \mathrm{~m}$ while the depth extent ranges from 31.91 to $175.5 \mathrm{~m}$, the maximum width of the bodies ranges from 13.93 to $370.45 \mathrm{~m}$. Tables 2 shows the rock types in the study area inferred from the susceptibility values. Rock types in the study area include limestone, sandstone, shale and schist. Others are Gneiss, Granite, Slate and Quartz. These rock types are of immense economic importance. It is therefore suggested to carry out geochemical analysis of samples of rocks in the study area for confirmation.

Table 2. Rock types in the Study Area with their susceptibility values

\begin{tabular}{|c|c|c|c|}
\hline $\begin{array}{l}\text { Profile } \\
\text { Name }\end{array}$ & $\begin{array}{l}\text { Causative } \\
\text { Bodies }\end{array}$ & $\begin{array}{l}\text { Susceptibility } \\
\text { Value SI }\end{array}$ & Rock Types \\
\hline $\mathbf{A A ^ { \prime }}$ & $\begin{array}{l}a^{\prime} \\
a^{\prime,} \\
a^{\prime,,} \\
a^{\prime,,,} \\
a^{,,,,,}\end{array}$ & $\begin{array}{l}0.9165 \\
2.1561 \\
0.7135 \\
2.2238 \\
1.1135\end{array}$ & $\begin{array}{l}\text { Limestone, Sandstone and Shale. } \\
\text { Schist and Gneiss }\end{array}$ \\
\hline $\mathbf{B B}^{\prime}$ & $\begin{array}{l}b^{\prime} \\
b^{\prime,} \\
b^{,,,} \\
b^{,,,,} \\
b^{,,,,,}\end{array}$ & $\begin{array}{l}0.7555 \\
1.4216 \\
-0.9299 \\
-1.2400 \\
0.6247\end{array}$ & $\begin{array}{l}\text { Limestone and Sandstone. } \\
\text { Slate and Granite }\end{array}$ \\
\hline $\mathbf{C C}^{\prime}$ & $\begin{array}{l}c^{\prime} \\
c^{\prime \prime}, \\
c^{\prime,}, \\
c^{\prime,,},\end{array}$ & $\begin{array}{l}1.6670 \\
3.1888 \\
1.2768 \\
1.4229\end{array}$ & $\begin{array}{l}\text { Limestone, Sandstone and Shale. } \\
\text { Schist, Gneiss, Slate and Granite }\end{array}$ \\
\hline DD' & $\begin{array}{l}d^{\prime} \\
d^{\prime,} \\
d^{\prime,}, \\
d^{\prime,,},\end{array}$ & $\begin{array}{l}-0.7194 \\
2.387 \\
5.3380 \\
-0.5897\end{array}$ & Slate and Granite \\
\hline EE' & $\begin{array}{l}e^{\prime} \\
e^{,}, \\
e^{,,}, \\
e^{,,,},\end{array}$ & $\begin{array}{l}1.1275 \\
1.5111 \\
-0.6745 \\
2.4492\end{array}$ & $\begin{array}{l}\text { Limestone, Sandstone and Shale. } \\
\text { Schist, Gneiss, Slate, Granite and } \\
\text { quartz veins }\end{array}$ \\
\hline
\end{tabular}




\section{CONCLUSION}

In this study, we modeled the ground magnetic data acquired from the study area to obtain the causative body parameters. The parameters obtained are depth to body with values ranging from 1.71 to $34.76 \mathrm{~m}$; depth extent with values ranging from 31.91 to $175.5 \mathrm{~m}$; maximum width with values ranging from 13.93 to $370.45 \mathrm{~m}$. the susceptibility vales obtained was used to infer the rock types in the study area to be limestone, sandstone, shale, schist, gneiss, granite, slate and quartz.

\section{REFERENCE}

1. Foley, J.E. (1994). Stolmstm Magnetic Survey at Sanda National Laboratory Technical Area 2, in proceedings of the Symposium on the Application of Geophysics to Engineering and Environmental Problems, March 27-37, Boston, Mass., edited by R.S. Bell and C.M. Lepper 895-907.

2. Gibson, P.J., Lyle, P. and Gorge, D.M. (1996). Environmental Geology 27: 178-183.

3. Machetti, M., Chiappini, M. and Meloni, A. (1998). A test site for magnetic detection of buried steel drums, Annal of Geophysics 41 (31): 491-498.

4. Nigerian Mining and Metal Sector Investment Brochure: (2017). Ministry of Mines and Steel Develpment

5. Shehu, S.J., Aku, M.O., Saleh, M., Bunawa, A.A Lawan, M and Sani, F (2021) The use of euler deconvolution technique in the estimation of depth to magnetic source bodies around the schist belt parts of kano State, Nigera. Jourdan Jurnal of Physics, volume 14, Number 1, pp 19-23.

6. Sheriff, T. W. (1928). Applied Geophysics. Science (New York, N.Y.) (2nd ed.,Vol.67). Cambridge UniversityPress.

7. Telford, W.M., Geldart, L.P, and Sheriff, R.E. (1990). Applied Geophysics, $2^{\text {nd }}$ edition, Cambridge University Press: London.

\section{Author: Jamaluddeen Sani Shehu}

${ }^{2}$ Department of Physics

Faculty of Science, Usmanu Danfodiyo University, Sokoto, Nigeria

email: shehujamal@gmail.com 